\title{
STC1 Gene
}

National Cancer Institute

\section{Source}

National Cancer Institute. STC1 Gene. NCI Thesaurus. Code C24836.

This gene plays a role in cellular calcium/phosphate homeostasis in both kidney and intestinal tissues. 